\title{
Evaluasi Kesesuaian Lahan untuk Tanaman Perkebunan di Wilayah Galela, Kabupaten Halmahera Utara, Propinsi Maluku Utara
}

\author{
Tri Mulya Hartati*1), Bambang Hendro Sunarminto ${ }^{2)}$, Makruf Nurudin ${ }^{2)}$ \\ ${ }^{1)}$ Program Studi Ilmu Tanah, Fakultas Pertanian, Universitas Khairun, Ternate \\ ${ }^{2)}$ Departemen Ilmu Tanah, Fakultas Pertanian, Universitas Gadjah Mada \\ *Corresponding author: trimulyahartati@gmail.com
}

\begin{abstract}
This study aims to determine land suitability class for of plantation crops, namely, coconut, clove, and cocoa in Galela region, North Halmahera, North Maluku. The determination of land suitability is determined by using the comparison method between the quality of the land on the condition of plant growth, the criteria using two methods, namely Simple Limitation Method (SLM) and Sys Criteria. The result showed the actual land suitability for coconut and clove using SLM system was obtained into two classes, S3 (marginally suitable) and N (unsuitable); whereas the potential land suitability was obtained into three classes i.e S2 (moderately suitable), S3 and N, for cocoa the actual and potential land suitability was obtained into classes $N$. While, according to Sys Criteria, the actual land suitability for coconut and clove the obtained two classes i.e. S2 and S3, the potential land suitability for coconut into three classes i.e $S 1$ (very suitable), S2, and S3, for clove into two classes S2, and S3, while for cocoa the actual and potential land suitability was obtained into classes S3. The generally, limiting factors in the cultivation of plantation crops in Galela region, North Halmahera, North Maluku include rooting media, nutrient retention, nutrient availability, erosion hazard, drainage, sodicity, and water availability. The supply of volcanic ash material from Mt. Dokuno positively affect the growth of plantation crops in Galela region. The approach method with Sys Criteria is well suited to determine the suitability of plantation land in the Galela region.
\end{abstract}

Keywords: Galela; Nutrient availability; Simple limitation method (SLM); Sys criteria

Cite this as: Hartati, T.M., Sunarminto, B.H., \& Nurudin, M. 2018. Evaluasi Kesesuaian Lahan untuk Tanaman Perkebunan di Wilayah Galela, Kabupaten Halmahera Utara, Propinsi Maluku Utara. Caraka Tani: Journal of Sustainable Agriculture. 33(1), 68-77. doi:http://dx.doi.org/10.20961/carakatani.v33i1.19298

\section{PENDAHULUAN}

Kawasan Galela merupakan bagian kecil daerah yang ada di Maluku Utara, terletak di kabupaten Halmahera Utara. Kawasan ini mendapat perhatian untuk dikembangkan tanaman perkebunan dengan pola pengembangan dititikberatkan pada perkebunan inti rakyat (Pemda Halmahera Utara, 2012). Beberapa komoditi tanaman perkebunan yang dihasilkan dari daerah ini antara lain kelapa, cengkeh dan kakao. Data sementara untuk produktivitas ratarata per tahun, pada tahun 2015, yaitu: kelapa 0,29 ton/ha, kakao 0,79 ton/ha, dan cengkeh 0,29 ton/ha (Dinas Pertanian Halmahera Utara, 2013; BPS, 2015). Bila dibandingkan dengan produktivitas nasional angka sementara untuk tanaman kelapa 1,16 ton/ha, kakao 0,82 ton/ha, dan cengkeh 0,30 ton/ha (Dirjenbun, 2015; BPS, 2015). Rendahnya produktivitas ini lebih disebabkan karena tidak semua lahan yang tersedia sesuai untuk ditanami tanaman perkebunan pada setiap satuan lahannya.

Evaluasi lahan adalah proses menduga potensi lahan dari waktu ke waktu sesuai dengan jenis penggunaan tertentu baik pertanian maupun untuk non pertanian (Zonneveld, 1989; Rossiter, 1996; Martin dan Saha, 2009; FAO, 2007; Sonneveld et al., 2010; Elsheikh et al., 2013). Prinsip tujuan evaluasi kesesuaian lahan pertanian adalah untuk memprediksi potensi dan faktor pembatas untuk produksi tanaman (Pan and Pan, 2012; Utomo et al., 2016). Penilaian kesesuaian lahan pertanian didefinisikan sebagai proses penilaian kinerja lahan saat digunakan untuk jenis pertanian 
alternatif (He et al., 2011; Mu, 2006; Prakash, 2003; Elsheikh et al., 2013).

Metode kriteria kesesuaian lahan berdasarkan sistem Limitasi Sederhana Djaenudin et al. (1994) dan Kriteria Sys et al. (1991) merupakan dua metode yang banyak digunakan untuk memprediksi hasil panen lokal dalam menentukan kesesuaian lahan pada berbagai tanaman (Wood dan Den, 1983). Kedua metode ini mengacu pada kerangka FAO (1976) yakni dengan membuat tabel kecocokan lahan berdasarkan karakteristik lahan atau kualitas lahan. Penilaian kesesuaian lahan dilakukan hingga tingkat sub kelas berdasarkan struktur klasifikasi kesesuaian lahan (FAO, 2007; Utomo et al., 2016), yaitu: S1 (sangat sesuai); S2 (cukup sesuai); S3 (sesuai marginal); dan $\mathrm{N}$ (tidak sesuai). Perbedaan penilaian kedua sistem ini, pada Limitasi Sederhana LPT Bogor (1983) penentu akhir dari tingkat kesesuaian lahan adalah nilai terburuk dari faktor penghambat terberat dari seluruh kelas kesesuaian lahan meskipun itu hanya satu parameter; sedangkan menurut Kriteria Sys et al. (1991), dengan menghitung semua kontribusi dari karakteristik lahan, selanjutnya dibuatkan penskoran nilai kelas, penjumlahan dari hasil skor diharapkan akan diperoleh penilaian secara obyektif dari seluruh parameter tanah yang dapat diamati di lapangan. Kedua metode ini sangat sederhana, mudah dipahami, dan memiliki presentasi grafis, namun kelemahannya tidak dapat menjelaskan interaksi antara karakteristik lahan (Elsheikh et al., 2013). Penelitian ini bertujuan untuk menentukan kelas kesesuaian lahan bagi tanaman kelapa, cengkeh, dan coklat di kawasan Galela.

\section{METODE PENELITIAN}

\section{Lokasi Penelitian}

Penelitian dilaksanakan mulai bulan Februari 2014 sampai Februari 2015 di kawasan Galela Kabupaten Halmahera Utara dan Laboratorium jurusan tanah Fakultas Pertanian Universitas Gadjah Mada. Secara administrasi kawasan Galela mencakup 4 kecamatan yaitu: Galela, Galela Utara, Galela Selatan, dan Galela Barat, terletak antara $01^{0} 14^{\prime} 20^{\prime \prime}-02^{\circ} 11^{\prime} 58^{\prime \prime}$ LU dan $127^{\circ}$ $43^{\prime} 24^{\prime \prime}-128^{0} 4^{\prime} 05^{\prime \prime}$ BT, dengan luas wilayah 63.479 ha. Jenis tanah lokasi penelitian diklasifikasikan ke dalam 5 ordo (Taksonomi Tanah, 2014), yaitu: Mollisol, Inceptisol, Entisol, Alfisol, dan Ultisol yang berkembang di bawah curah hujan $2.417,1 \mathrm{~m} /$ tahun dengan suhu udara rata-rata $26,1^{\circ} \mathrm{C}$, memiliki iklim $\mathrm{B}(\mathrm{Q}=0,2065)$ yakni basah, dengan rejim kelembaban tanah Udik.

Kondisi topografi di wilayah Galela bervariasi antara datar hingga sangat curam. Hasil interpretasi peta rupa bumi skala 1:50.000 tahun 2008 menunjukkan kemiringan lereng yang terluas di wilayah Galela adalah agak curamsangat curam yaitu $33.341,7$ ha (51\%). Geologi di wilayah Galela merupakan bagian dari lengan barat pulau Halmahera yang merupakan rangkaian pegunungan berapi bercampur batuan sedimen angkatan.

\section{Metode Penelitian}

Metode penelitian didasarkan pada beberapa tahapan yaitu:

a. Pembuatan Satuan Peta Tanah (SPT).

SPT diperoleh dengan cara menumpang susunkan (overlapping) peta geologi (Peta Geologi Lembar Morotai skala 1:250.000 tahun 1981), peta penggunaan lahan (land use) (Citra Landsat ETM 7 + tahun 2011), peta lereng (Peta Land system skala 1:250.000 tahun 1995) dan peta RBI (RBI digital skala 1:50.000 tahun 2008).

b. Survei Lapang dan Pengumpulan Data.

Tahap ini dilakukan melalui survei tanah pada satuan-satuan lahan (land unit) yang telah dituangkan dalam SPT skala 1:50.000. Kegiatan survei utama pada lokasi penelitian, dengan Sistem Transek pada seluruh area penelitian yang telah ditentukan berdasarkan Peta SPT, dengan membuat minipit atau bor sebanyak 104 titik. Sampel tanah hasil boring dianalisis di lapangan dengan menggunakan analisis selidik cepat ciri tanah (Notohadiprawiro, 1985). Setelah diperoleh keseragaman selanjutnya dideliniasikan untuk menentukan profil tanah pewakil sebanyak 17 profil. Contoh tanah diambil secara terusik dan tidak terusik pada kedalaman $0-20 \mathrm{~cm}$ dan 20-50 cm, contoh tanah terpilih selanjutnya dianalisis sifat fisika dan kimia di laboratorium. Untuk data iklim, data diambil selama 10 tahun pencatatan (tahun 2006 - 2016) yang dikumpulkan dari stasiun iklim setempat yaitu Stasiun Meteorologi dan Geofisika Gamarmalamo Galela, berupa data: curah hujan $(\mathrm{mm})$, suhu udara $\left({ }^{\circ} \mathrm{C}\right)$, dan kelembaban udara (\%). 


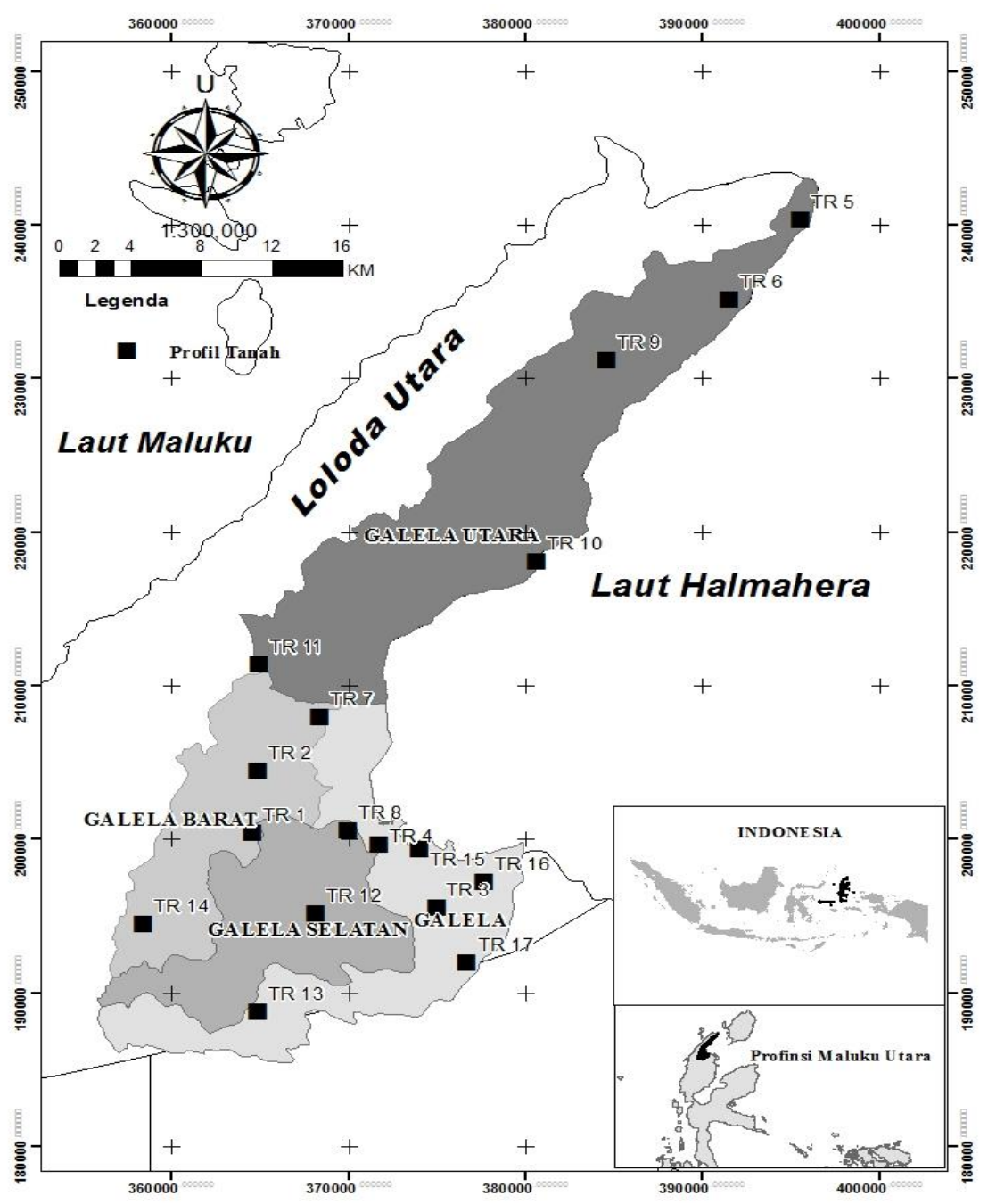

Gambar 1. Lokasi Penelitian Analisis Tanah

Contoh tanah dianalisis di laboratorium Jurusan Tanah Fakultas Pertanian, Universitas Gadjah Mada meliputi sifat fisik dan kimia tanah. Adapun sifat-sifat fisik tanah yang dianalisis terdiri dari: tekstur metode Pipet, Berat Volume metode ring, Berat Jenis menggunakan Piknometer (Kertonegoro et al., 1998; Balittanah, 2009), dan Porositas. Sedangkan sifat-sifat kimia yang dianalisis terdiri dari: $\mathrm{pH} \mathrm{H}_{2} \mathrm{O}, \mathrm{pH} \mathrm{KCl}$, dan $\mathrm{pH} \mathrm{NaF}$ dengan $\mathrm{pH}$ meter $(1: 2,5)$, DHL dengan EC meter (1:5), C-Organik metode Walkley dan Black, N-Total metode Kjeldahl, $\mathrm{P}$-Tersedia metode Olsen, $\mathrm{K}$ tersedia dengan ekstrak ammonium acetate $1 \mathrm{M} \mathrm{pH} 7$, Kapasitas Pertukaran Kation (KPK) dengan ekstrak ammonium acetate $1 \mathrm{M} \mathrm{pH}$ 7, Kationkation Basa $\left(\mathrm{Ca}^{2+}, \mathrm{Mg}^{2+}, \mathrm{K}^{+}, \mathrm{Na}^{+}\right)$dengan ekstrak ammonium acetate $1 \mathrm{M} \mathrm{pH} 7, \mathrm{Ca}^{2+}$ dan $\mathrm{Mg}^{2+}$ diukur menggunakan AAS sementara
$\mathrm{K}^{+}$, dan $\mathrm{Na}^{+}$diukur menggunakan Flamefotometer, Kejenuhan Basa dan Presentase Kejenuhan Natrium (ESP) (BPT, 2009).

c. Kompilasi Data.

Data tanah hasil analisis laboratorium dilengkapi dengan data iklim selanjutnya diolah dengan rata-rata tertimbang dan ratarata aritmetika. Pengharkatan nilai rata-rata hasil perhitungan sifat-sifat kimia tanah berdasarkan kriteria pengharkatan sifat kimia tanah menurut BPT (2009), sedangkan sifatsifat fisika menurut Kertonegoro et al. (1998).

d. Interprestasi dan Penyajian Data.

Penentuan kesesuaian lahan aktual (current suitability) dari setiap satuan lahan dalam penelitian ini ditentukan dengan menggunakan metode pembandingan (matching) antara kualitas lahan dengan syarat tumbuh tanaman tanpa ada perbaikan terhadap faktor pembatas. 
Kriteria kesesuaian lahan menggunakan dua metode, yakni berdasarkan sistem Limitasi Sederhana LPT Bogor (1983) cit. Djaenudin et al. (1994) dan Kriteria Sys et al. (1991). Kesesuaian lahan potensial ditentukan dengan mempertimbangkan masukan dan tindakan pengelolaan yang diberikan pada setiap satuan lahan, dengan asumsi setelah diadakan usahausaha perbaikan terhadap faktor-faktor pembatasnya, kemudian dilakukan pembandingan kembali dengan syarat tumbuh tanaman pertanian.

\section{HASIL DAN PEMBAHASAN}

Berdasarkan hasil pengamatan di lapangan dan ditunjang dengan data analisis laboratorium, hasil pemadanan antara karakteristik lahan dan persyaratan tumbuh tanaman, penilaian kesesuaian lahan dengan dua metode yang digunakan menunjukkan adanya variasi kesesuaian lahan untuk tanaman kelapa, cengkeh, dan coklat. Untuk tanaman kelapa dan cengkeh hasil evaluasi kesesuaian lahan aktual dengan sistem Limitasi Sederhana diperoleh 2 kelas yakni $\mathrm{N}$ (tidak sesuai) dan kelas S3 (sesuai marginal), sedangkan dengan sistem Kriteria Sys semua lahan dapat ditanami tanaman kelapa dan cengkeh, namun pada kelas yang berbeda, yakni kelas S3 dan kelas S2 (cukup sesuai). Sementara untuk tanaman coklat hasil evaluasi kesesuaian lahan dengan kedua pendekatan menunjukkan hasil yang tidak sesuai dalam arti tanaman coklat tidak cocok ditanam di wilayah ini. Hasil penilaian kesesuaian lahan aktual dan potensial tersaji pada Tabel 1 dan Tabel 2.

Tabel 1. Kelas Kesesuaian Lahan Aktual Untuk Tanaman Kelapa, Cengkeh dan Coklat di Wilayah Galela Kabupaten Halmahera Utara Propinsi Maluku Utara

\begin{tabular}{|c|c|c|c|c|c|c|c|c|}
\hline \multirow{3}{*}{ SPT } & \multicolumn{6}{|c|}{ Kesesuaian Lahan Aktual } & \multirow{2}{*}{\multicolumn{2}{|c|}{ Luas }} \\
\hline & \multicolumn{3}{|c|}{ Limitasi Sederhana } & \multicolumn{3}{|c|}{ Kriteria Sys } & & \\
\hline & Kelapa & Cengkeh & Coklat & Kelapa & Cengkeh & Coklat & $\mathrm{Ha}$ & $\%$ \\
\hline 1 & S3na & S3naxn & Nwa & S2na & S3naxn & S3wa & 4.489 & 7 \\
\hline 2 & $\mathrm{Nrc}$ & $\mathrm{Nrc}$ & Nwarc & S3rc & S3rc & S3warc & 7866 & 12 \\
\hline 3 & S3oarcna & Nxn & Nwa & S2oarcna & S3xn & S3wa & 1.471 & 2 \\
\hline 4 & S3na & Nxn & Nwa & S2na & S3xn & S3wa & 988 & 2 \\
\hline 5 & $\mathrm{Nrc}$ & $\mathrm{Nrc}$ & Nwarc & S3rc & S3rc & S3warc & 1250 & 2 \\
\hline 6 & S3naeh & S3naeh & Nwa & S2naeh & S2naeh & S3wa & 5254 & 8 \\
\hline 7 & S3oana & S3oanaxn & Nwa & S2oana & S3oanaxn & S3wa & 4.707 & 7 \\
\hline 8 & S3na & S3naxn & Nwa & S2na & S2naxn & S3wa & 342 & 1 \\
\hline 9 & S3na & S3nrna & Nwa & S2na & S2nrna & S3wa & 1867 & 3 \\
\hline 10 & S3na & S3nrna & Nwa & S2na & S2nrna & S3wa & 496 & 1 \\
\hline 11 & Neh & Neh & Nwaeh & S3eh & S3eh & S3waeh & 15094 & 24 \\
\hline 12 & S3na & S3naeh & Nwa & S2na & S2naeh & S3wa & 2387 & 4 \\
\hline 13 & S3naeh & S3naeh & Nwa & S2naeh & S2naeh & S3wa & 6592 & 10 \\
\hline 14 & S3na & Nxn & Nwa & S2na & S3xn & S3wa & 682 & 1 \\
\hline 15 & $\mathrm{Nrc}$ & $\mathrm{Nrc}$ & Nwarc & S3rc & S3rc & S3warc & 2930 & 5 \\
\hline 16 & Neh & $\mathrm{Neh}$ & Nwaeh & S3eh & S3eh & S3waeh & 5299 & 8 \\
\hline 17 & S3naeh & S3naeh & Nwa & S2naeh & S2naeh & S3wa & 1765 & 3 \\
\hline \multicolumn{7}{|c|}{ Jumlah } & 63.479 & 100 \\
\hline
\end{tabular}

Keterangan: SPT = Satuan Peta Tanah, Kelas kesesuaian lahan yang ditulis dalam angka adalah jumlah harkat dan huruf besar yang diikuti oleh angka dan huruf kecil menunjukkan tingkat dan faktor pembatas kelas kesesuaian lahan. (Utomo et al., 2016). $\mathrm{N}$ = tidak sesuai, S3 = sesuai marginal, $\mathrm{S} 2$ = cukup sesuai, $\mathrm{rc}=$ faktor pembatas media perakaran, eh= faktor pembatas bahaya erosi, oa $=$ faktor pembatas ketersediaan oksigen, $\mathrm{na}=$ faktor pembatas hara tersedia, $\mathrm{nr}=$ faktor pembatas retensi hara, $\mathrm{wa}=$ faktor pembatas ketersesiaan air, $\mathrm{xn}=$ faktor pembatas sodisitas 
Tabel 2. Kelas Kesesuaian Lahan Potensial Untuk Tanaman Kelapa, Cengkeh dan Coklat di Wilayah Galela Kabupaten Halmahera Utara Propinsi Maluku Utara

\begin{tabular}{|c|c|c|c|c|c|c|c|c|}
\hline \multirow{3}{*}{ SPT } & \multicolumn{6}{|c|}{ Kesesuaian Lahan Potensial } & \multirow{2}{*}{\multicolumn{2}{|c|}{ Luas }} \\
\hline & \multicolumn{3}{|c|}{ Limitasi Sederhana } & \multicolumn{3}{|c|}{ Kriteria Sys } & & \\
\hline & Kelapa & Cengkeh & Coklat & Kelapa & Cengkeh & Coklat & $\mathrm{Ha}$ & $\%$ \\
\hline 1 & S2na & S3xn & Nwa & S1na & S2xn & S3wa & 4.489 & 7 \\
\hline 2 & $\mathrm{Nrc}$ & $\mathrm{Nrc}$ & Nwarc & S3rc & $\mathrm{S} 3 \mathrm{rc}$ & S3warc & 7866 & 12 \\
\hline 3 & S3oarc & Nxn & Nwa & S2oarc & S3xn & S3wa & 1.471 & 2 \\
\hline 4 & S2rcnaeh & Nxn & Nwa & S2rcnaeh & S3xn & S3wa & 988 & 2 \\
\hline 5 & $\mathrm{Nrc}$ & $\mathrm{Nrc}$ & Nwarc & S3rc & $\mathrm{S} 3 \mathrm{rc}$ & S3warc & 1250 & 2 \\
\hline 6 & S3eh & S3eh & Nwa & S2eh & S2eh & S3wa & 5254 & 8 \\
\hline 7 & S3oa & S3oaxn & Nwa & S2oa & S2oaxn & S3wa & 4.707 & 7 \\
\hline 8 & S2naeh & S3xn & Nwa & S2naeh & S2xn & S3wa & 342 & 1 \\
\hline 9 & S2rcnaeh & S2warceh & Nwa & S1rcnaeh & S2warceh & S3wa & 1867 & 3 \\
\hline 10 & S2naeh & S2warceh & Nwa & S2naeh & S2warceh & S3wa & 496 & 1 \\
\hline 11 & Neh & Neh & Nwaeh & S3eh & S3eh & S3waeh & 15094 & 24 \\
\hline 12 & S2rcnaeh & S2warceh & Nwa & S1rcnaeh & S2warceh & S3wa & 2387 & 4 \\
\hline 13 & S3eh & S3xn & Nwa & S2eh & S2xn & S3wa & 6592 & 10 \\
\hline 14 & S2rcnaeh & Nxn & Nwa & S2rcnaeh & S3xn & S3wa & 682 & 1 \\
\hline 15 & $\mathrm{Nrc}$ & $\mathrm{Nrc}$ & Nwarc & S3rc & S3rc & S3warc & 2930 & 5 \\
\hline 16 & Neh & Neh & Nwaeh & S3eh & S3eh & S3waeh & 5299 & 8 \\
\hline 17 & S3eh & S3eh & Nwa & S2eh & S2eh & S3wa & 1765 & 3 \\
\hline \multicolumn{7}{|c|}{ Jumlah } & 63.479 & 100 \\
\hline
\end{tabular}

Keterangan: SPT $=$ Satuan Peta Tanah, Kelas kesesuaian lahan yang ditulis dalam angka adalah jumlah harkat dan huruf besar yang diikuti oleh angka dan huruf kecil menunjukkan tingkat dan faktor pembatas kelas kesesuaian lahan. (Utomo et al., 2016). $\mathrm{N}$ = tidak sesuai, $\mathrm{S} 3$ = sesuai marginal, $\mathrm{S} 2$ = cukup sesuai, $\mathrm{S} 1$ = Sangat sesuai, $\mathrm{rc}=$ faktor pembatas media perakaran, $\mathrm{eh}=$ faktor pembatas bahaya erosi, $\mathrm{oa}=$ faktor pembatas ketersediaan oksigen, $\mathrm{na}=$ faktor pembatas hara tersedia, $\mathrm{wa}=$ faktor pembatas ketersesiaan air, $\mathrm{xn}=$ faktor pembatas sodisitas

Dari hasil evaluasi dengan ke dua metode tersebut, nampak dijumpai beberapa faktor pembatas pada budidaya tanaman kelapa dan cengkeh di wilayah Galela Kabupaten Halmahera Utara, seperti media perakaran (kedalaman tanah) (rc) retensi hara (nr), ketersediaan hara (na), bahaya erosi (eh), drainase (oa), dan sodisitas (xn).

Solum tanah menunjukkan kedalaman akar tanaman dapat mencapai dan menggunakan air serta nutrisi yang tersedia (Akinci et al., 2013; Utomo et al., 2016). Solum tanah juga memberikan gambaran tentang tingkat pelapukan bahan induk dari suatu tanah. Tanah yang memiliki solum yang dalam memberikan gambaran tingkat pelapukan bahan induk yang sudah lanjut. Berdasarkan hasil pengamatan di lapangan, lokasi penelitian memiliki kedalaman yang berbeda-beda. Kedalaman tanah dapat menjadi faktor penghambat bagi pertumbuhan tanaman perkebunan yang berhubungan dengan penetrasi akar. Faktor pembatas kedalaman tanah yang dijumpai pada wilayah ini adalah media perakaran yang dangkal pada kedalaman $\geq 20 \mathrm{~cm}$ berupa lapisan kerikil terumbu koral, seperti pada SPT TR 5. Selain solum yang dangkal, tanah juga memiliki kelekatan yang cukup lekat pada lapisan olah. Kenyataan di lapangan untuk tanah-tanah seperti ini tidak dijumpai tanaman cengkeh maupun coklat disekitarnya. Pada SPT TR 2, dijumpai lapisan padas namun lapisan ini masih dapat diperbaiki dengan cara membongkarnya pada waktu pengolahan tanah, disini tanaman cengkeh masih dapat tumbuh apalagi kelapa. Namun sebagai skala perkebunan rakyat anjuran perbaikan dengan membongkarnya pada waktu pengolahan sangat membutuhkan biaya dan tenaga yang cukup tinggi, petani tidak dapat melakukannya. Sehubungan dengan hal tersebut, hasil evaluasi kesesuaian lahan aktual maupun potensial pada penilaian dengan sistem Limitasi Sederhana LPT Bogor menunjukkan lahan pada TR 5 dan TR 2 termasuk sub kelas N (tidak sesuai untuk saat ini), sedangkan penilaian dengan sistem Kriteria Sys termasuk kelas S3 (sesuai 
marginal). Gambar peta kesesuaian lahan aktual dan potensial tersaji pada Gambar $1-2$.

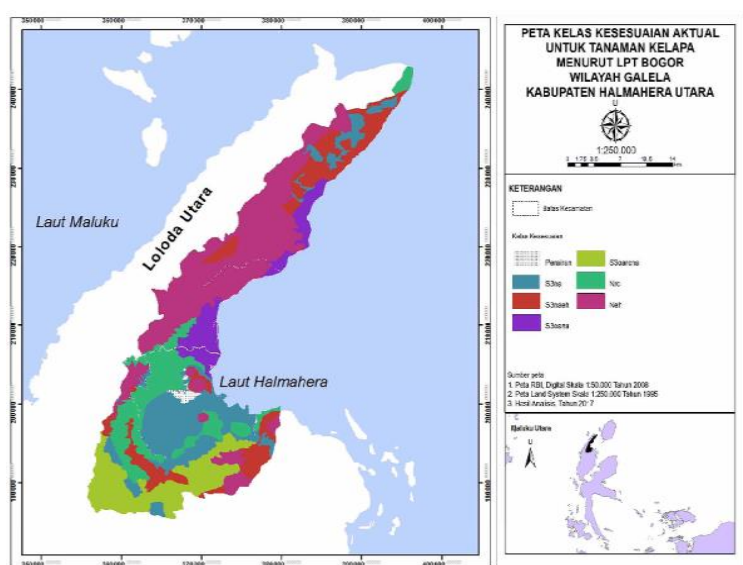

$1 \mathrm{a}$

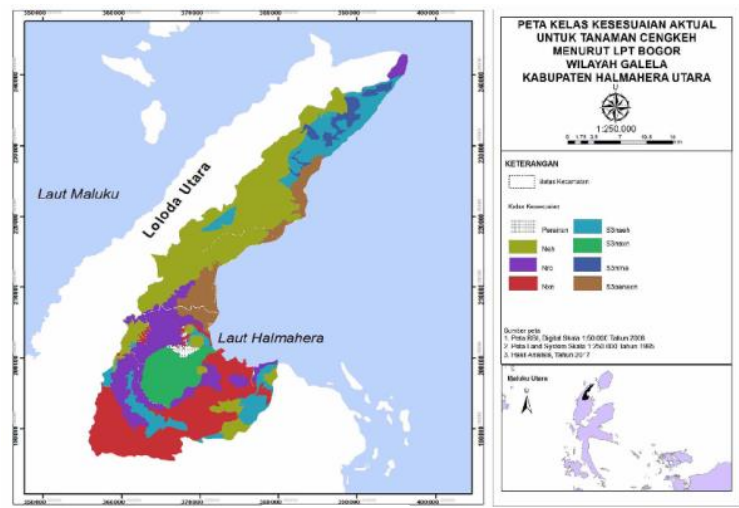

$1 \mathrm{c}$

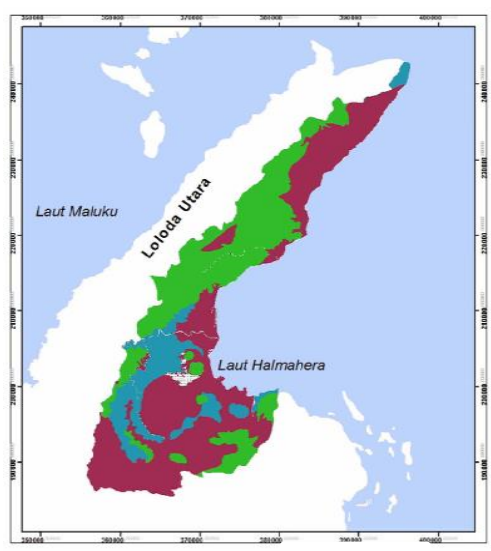

$1 \mathrm{e}$

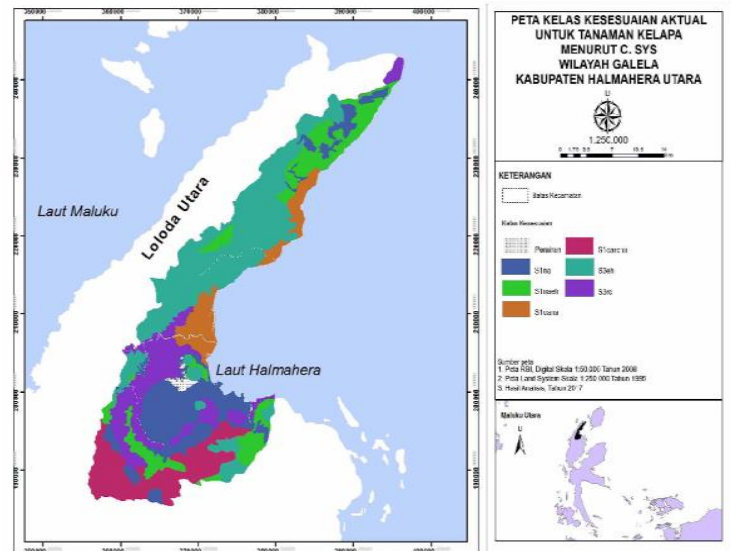

$1 \mathrm{~b}$

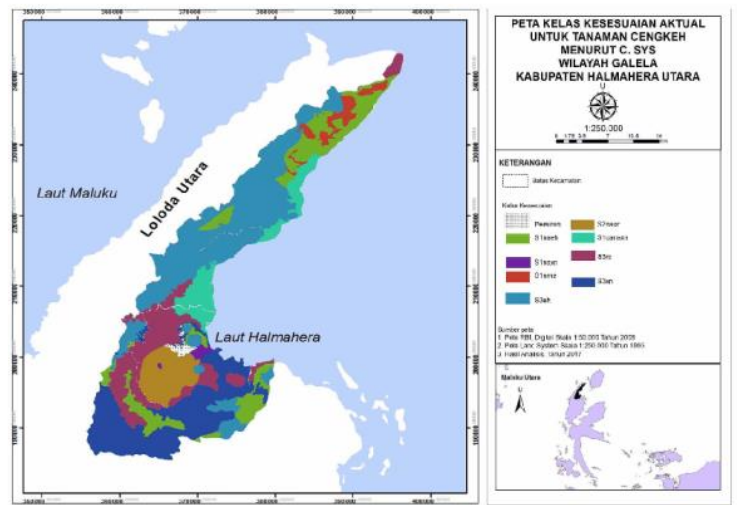

$1 d$

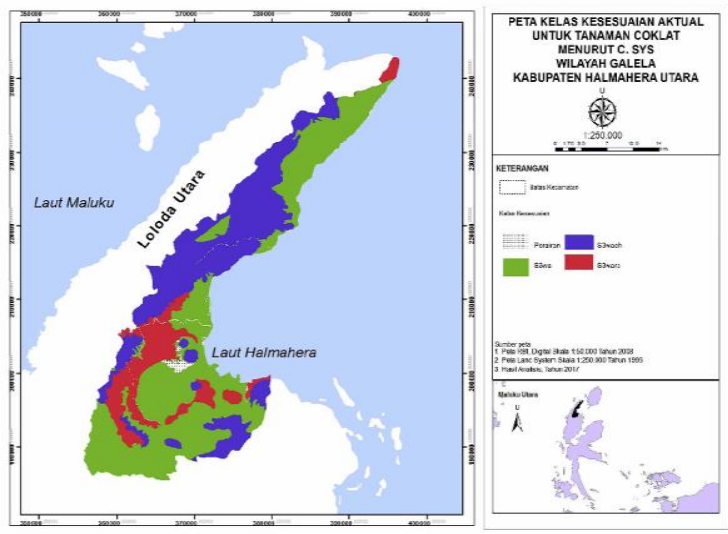

1f

Gambar 1. Peta Kelas Kesesuaian Lahan Aktual

$1 \mathrm{a}=$ Peta Kelas Kesesuaian Lahan Aktual Tanaman Kelapa Menurut LPT Bogor; $1 \mathrm{~b}=$ Peta Kelas Kesesuaian Lahan Aktual Tanaman Kelapa Menurut C. Sys; 1c = Peta Kelas Kesesuaian Lahan Aktual Tanaman Cengkeh Menurut LPT Bogor; 1d = Peta Kelas Kesesuaian Lahan Aktual Tanaman Cengkeh Menurut C. Sys; 1e = Peta Kelas Kesesuaian Lahan Aktual Tanaman Kakao Menurut LPT Bogor; 1f = Peta Kelas Kesesuaian Lahan Aktual Tanaman Kakao Menurut C. Sys. 


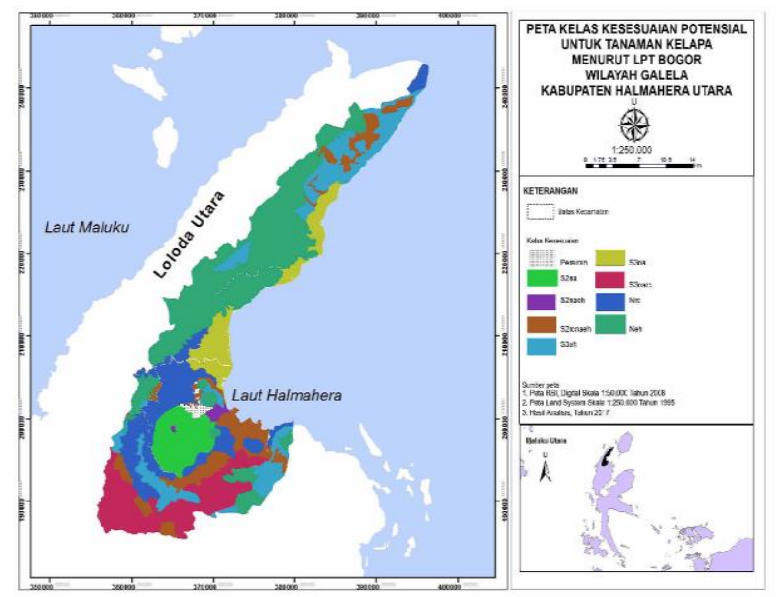

$2 \mathrm{a}$
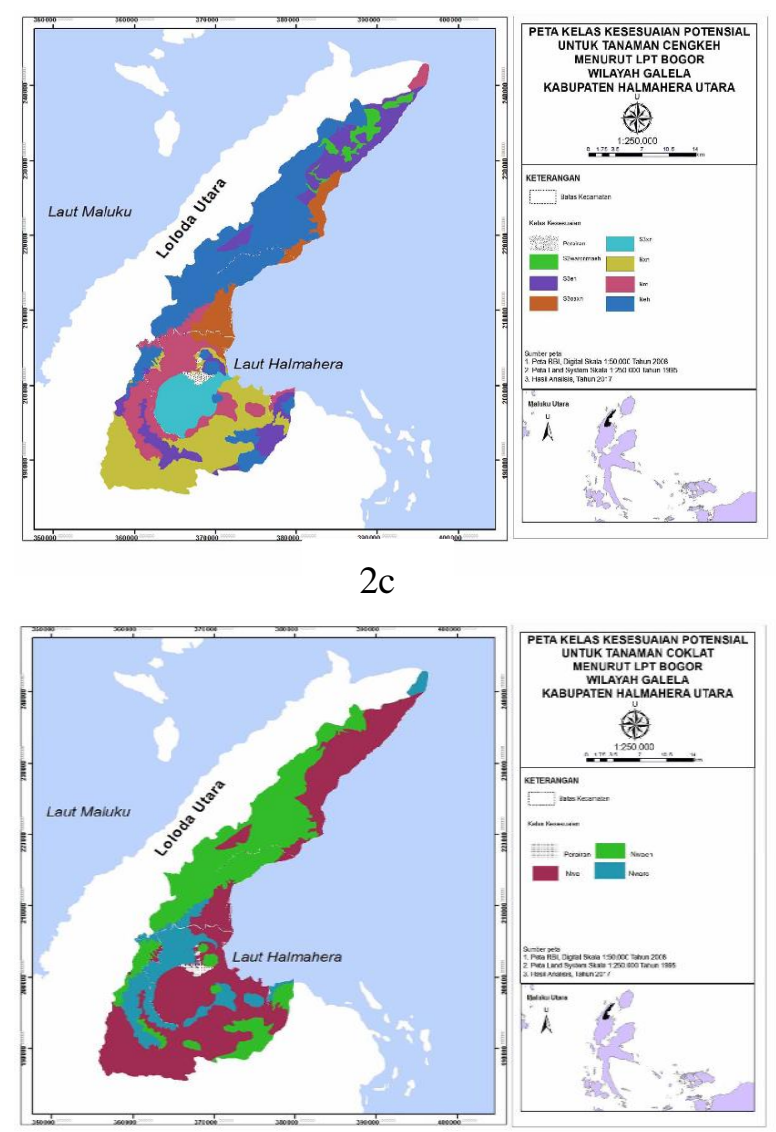

$2 \mathrm{e}$

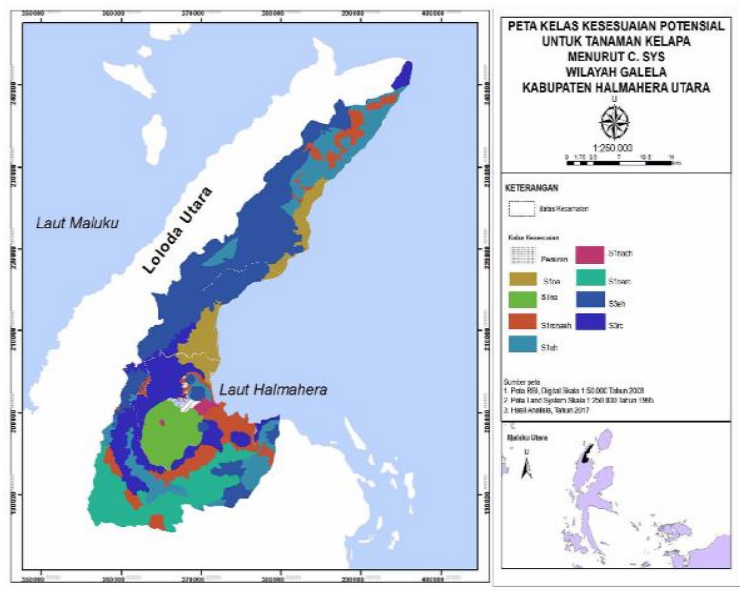

$2 b$
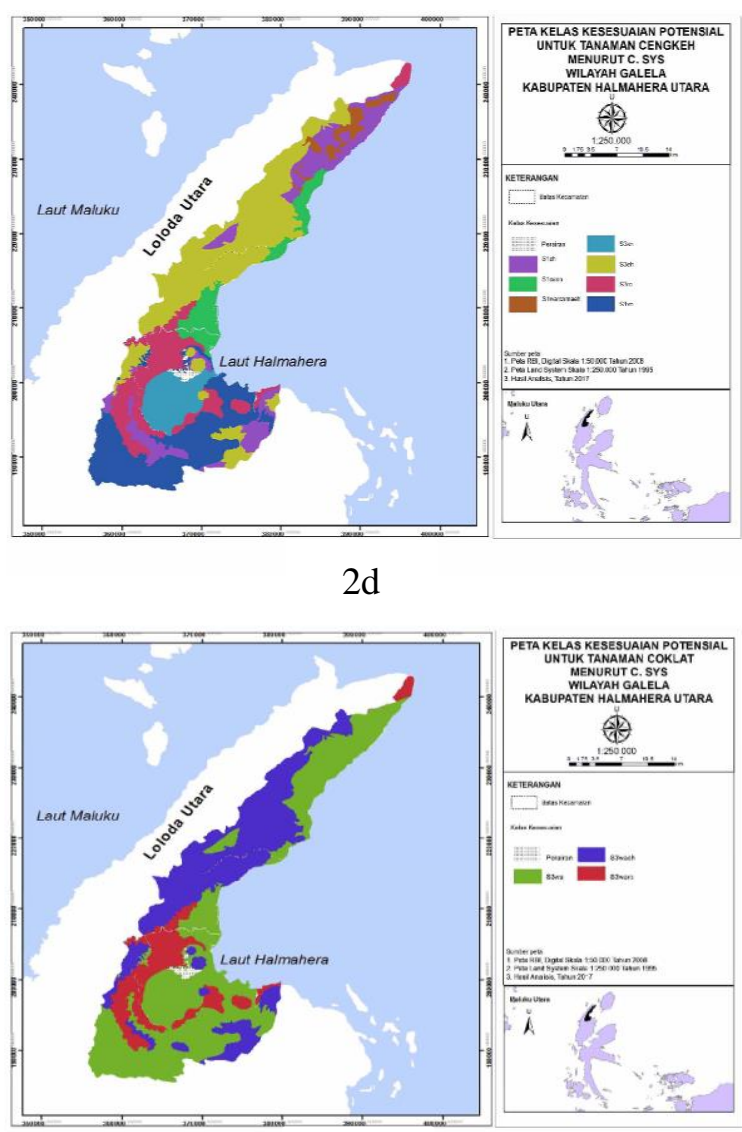

$2 \mathrm{f}$

Gambar 2. Peta Kelas Kesesuaian Lahan Potensial

$2 \mathrm{a}=$ Peta Kelas Kesesuaian Lahan Potensial Tanaman Kelapa Menurut LPT Bogor; $2 \mathrm{~b}=$ Peta Kelas Kesesuaian Lahan Potensial Tanaman Kelapa Menurut C. Sys; $2 \mathrm{c}=$ Peta Kelas Kesesuaian Lahan Potensial Tanaman Cengkeh Menurut LPT Bogor; 2d = Peta Kelas Kesesuaian Lahan Potensial Tanaman Cengkeh Menurut C. Sys; 2e = Peta Kelas Kesesuaian Lahan Potensial Tanaman Kakao Menurut LPT Bogor; $2 \mathrm{f}=$ Peta Kelas Kesesuaian Lahan Potensial Tanaman Kakao Menurut C. Sys

Faktor pembatas retensi hara dan ketersediaan hara untuk penggunaan jangka panjang merupakan faktor pembatas yang masih dapat dilakukan perbaikan misalnya melalui pemberian bahan organik dan pemupukan dengan tingkat pengelolaan yang tergolong rendah, artinya pengelolaan masih dapat dilakukan oleh petani dengan biaya yang relatif rendah. Jenis perbaikan 
untuk faktor penghambat retensi hara (nr) dan ketersediaan hara (na) dapat dilakukan dengan pemberian pupuk organik dan pemberian pupuk buatan. Penggunaan pupuk buatan yang bersamaan dengan pupuk organik pada tanah pasir atau tanah yang banyak tererosi dapat menghambat pelindian oleh air hujan dan juga terjadinya erosi. Hasil evaluasi kesesuaian lahan aktual penilaian dengan sistem Limitasi Sederhana LPT Bogor menunjukkan lahan-lahan dengan faktor pembatas retensi hara dan ketersediaan hara termasuk dalam sub kelas S3 (sesuai marginal), sedangkan penilaian dengan sistem Kriteria Sys termasuk kelas S2 (cukup sesuai) dan S3 (sesuai marginal). Hasil evaluasi kesesuaian lahan potensial, penilaian dengan sistem Limitasi Sederhana LPT Bogor termasuk dalam sub kelas S2 (cukup sesuai), sedangkan penilaian dengan sistem Kriteria Sys termasuk kelas S2 (cukup sesuai) dan S3 (sesuai marginal).

Sekitar 20.567 ha $(32 \%)$ wilayah penelitian memiliki kelerengan 50-70\%, yaitu pada TR 10 dan TR 12. Penggunaan lahan pada TR 10 digunakan sebagai lahan hutan dengan vegetasi tanaman hutan seperti Aren dan Tagalolo, sedangkan pada TR 12 meskipun dengan kemiringan yang cukup landai petani setempat masih menggunakannya sebagai kebun campuran. Adanya gunung api yaitu gunung Dokuno menghasilkan material vulkanis yang cukup subur, sehingga meskipun dengan kemiringan lereng yang cukup landai tanaman pala masih dapat tumbuh di daerah ini. Hasil evaluasi kesesuaian lahan aktual dan potensial penilaian dengan sistem Limitasi Sederhana LPT Bogor menunjukkan lahan pada TR 10 dan TR 12 termasuk sub kelas $\mathrm{N}$ (tidak sesuai untuk saat ini), sedangkan penilaian dengan sistem Kriteria Sys termasuk kelas S3 (sesuai marginal). Tingginya intensitas dan curah hujan pada lahan dengan kemiringan lereng yang landai sampai curam dapat menyebabkan erosi juga cukup tinggi (Arsyad, 2010; Utomo et al., 2016). Usaha pengurangan laju erosi memang dapat dilakukan dengan pembuatan teras, penanaman sejajar kontur maupun penanaman tanaman penutup tanah, namun dengan kelerengan yang lebih dari $30 \%$ upaya tindakan pengelolaan untuk mengatasi faktor pembatas pada lahan ini tentu membutuhkan biaya yang cukup tinggi.
Drainase yang sangat cepat ataupun yang sangat terhambat, merupakan pembatas yang tidak dapat diabaikan juga dalam budidaya tanaman perkebunan. Usaha perbaikan sistem drainase dengan pembuatan saluran drainase, membutuhkan tingkat pengelolaan sedang-tinggi. Pada wilayah penelitian daerah yang memiliki masalah dalam drainase dijumpai pada TR 6. Pada TR 6 selain faktor pembatasnya ketersediaan hara (na) lahan ini juga memiliki faktor pembatas drainase (oa) dan alkalinitas/ESP (xn). Adanya pengaruh gleisiasi pada kedalaman $\pm 25 \mathrm{~cm}$ disebabkan oleh adanya genangan. Hasil evaluasi kesesuaian lahan aktual maupun potensial pada penilaian dengan sistem Limitasi Sederhana LPT Bogor menunjukkan lahan pada SPT TR 6 termasuk sub kelas S3 (sesuai marginal), sedangkan dengan Kriteria Sys hasil evaluasi kesesuaian aktualnya termasuk sub kelas S3, namun evaluasi kesesuaian potensialnya termasuk sub kelas S2.

Hasil penilaian kesesuaian lahan dengan sistem Kriteria Sys ternyata lebih sesuai dalam penentuan kelas kesesuaian lahan di wilayah Galela. Kondisi ini didukung pula oleh kenyataan yang dapat dilihat di lapangan pada waktu survey dan pengambilan data lapangan, bahwa lahanlahan marginal yang dalam sistem Limitasi Sederhana dinyatakan tidak sesuai, ternyata tanaman kelapa, cengkeh dan coklat masih dapat tumbuh dengan baik.

\section{KESIMPULAN}

Berdasarkan hasil dan pembahasan kesimpulan yang dapat diambil, Sistem Kriteria Sys lebih sesuai dalam penentuan kelas kesesuaian lahan untuk tanaman kelapa, cengkeh dan coklat di wilayah Galela. Evaluasi kesesuaian lahan dengan sistem Kriteria Sys untuk tanaman kelapa diperoleh kelas S3 dengan luas 32.439 ha (51\%) dan kelas S2 dengan luas 31.040 ha (49\%); untuk tanaman cengkeh diperoleh kelas S3 dengan luas 35.580 ha (56\%), kelas S2 dengan luas 342 ha (1\%), dan kelas S1 dengan luas 27.557 ha (43\%); dan untuk tanaman coklat semua lahan masuk dalam kriteria S3. Secara umum faktor pembatas dalam budidaya tanaman perkebunan di wilayah Galela, meliputi: retensi hara, ketersediaan hara, media perakaran, erosi, drainase, dan sodisitas. 


\section{DAFTAR PUSTAKA}

-----. 2007. Land Evaluation. Towards a Revised Framework. FAO of the United Nations, Rome, Italy. $107 \mathrm{pp}$.

Akinci H., Ozalp, A.Y., \& Turgut, B. 2013. Agricultural land use suitability analysis using GIS and AHP technique. Computers and Electronics in Agriculture. 97, 71-82.

Arsyad, S. 2010. Konservasi Tanah dan Air. Edisi Kedua. IPB Press. Bogor.

Badan Penelitian dan Pengembangan PertanianKementerian Pertanian. 2011. Petunjuk Teknis Evaluasi Lahan Untuk Komoditas Pertanian. Balai Besar Penelitian dan Pengembangan Sumberdaya Lahan Pertanian, Badan Penelitian dan Pengembangan Pertanian, Bogor. 166 hal.

Badan Pusat Statistik. 2015. Maluku Utara Dalam Angka. BPS Propinsi Maluku Utara.

Balai Penelitian Tanah. 2009. Analisis Kimia Tanah, Tanaman, Air dan Pupuk. Petunjuk Teknis Edisi 2. Balai Penelitian Tanah. Bogor.

Dinas Pertanian Halmahera Utara. 2012. Luas Areal dan Produksi Komoditi Tanaman Perkebunan Halmahera Utara.

Direktorat Jenderal Perkebunan. 2014. Luas Areal dan Produksi Tanaman Perkebunan Rakyat Menurut Jenis Tanaman, 2000-2014.

Djaenudin D., Basuni, Hardjowigeno, S., Subagyo, H., Sukardi, M., Ismangun, Marsudi, Suharta, N., Hakim, L., Widagdo, Dai, J., Suwandi, V., Bachri S., \& Jordens, E.R. 1994. Kesesuaian Lahan Untuk Tanaman Pertanian dan Tanaman Kehutanan. Laporan Teknis No. 7. Versi 1,0. P.T. Andal Agrikarya Prima. Centre For Soil and Agroclimate Research. Bogor.

Elsheikh, R., Shariff, A.R.B.M., Amiri, F., Ahmad, N.B., Balasundram, S.K., \& Soom, M.A.M. 2013. Agriculture Land Suitability Evaluator (ALSE): A Decision and Planning Support Tool for Tropical and Subtropical Crops. Computer and Electronics in Agriculture. 93, 98-110.

FAO. 1976. A Framework for Land Evaluation. Food and Agriculture Organization of the
United Nations, Soil Bulletin 32. FAO, Rome. Italy

He, Y., Yao, Y., Chen, Y., \& Ongaro, I. 2011. Regional Land Suitability Assessment for Tree Crops Using Remote Sensing and GIS. Computer Distributed Control and Intelligent Environmental Monitoring (CDCIEM) IEEE, Changsha, pp. $354-363$.

Kertonegoro, B.D., Suparnawa, S.H., Notohadisuwarno, \& Handayani, S. 1998. Panduan Analisis Fisika Tanah. Jurusan Tanah Fakultas Pertanian Universitas Gadjah Mada. Yogyakarta

Martin, D., \& Saha, S.K. 2009. Land Evaluation by Integrating Remote Sensing and GIS for Cropping System Analysis in a Watershed. Current Science. 96(4), 569-575.

Mu, Y. 2006. Developing a Suitability Index for Residential Land Use: A Case Study in Dianchi Drainage Area. University of Waterloo, Canada.

Notohadiprawiro, T.R.M. 1985. Selidiki Cepat Ciri Tanah di Lapangan. Cet. I. Penerbit Ghalia Indonesia

Pan, G., \& Pan, J. 2012. Research in Crop Land Suitability Analysis Based on GIS. Computer and Computing Technologies in Agriculture. 365, 314-325.

Pemerintah Daerah Kabupaten Halmahera Utara. 2012. Rencana Tata Ruang Wilayah (RTRW) Kabupaten Halmahera Utara Tahun 20122032. Peraturan Daerah Kabupaten Halmahera Utara Nomor 09 Tahun 2012.

Prakash, T.N. 2003. Land Suitability Analysis for Agricultural Crops: A Fuzzy Multicriteria Decission Making Approach, Science in Geoinformatics. ITC, Netherlands, pp. 6-13

Rossiter, D.G. 1996. A Theoretical Framework for Land Evaluation. Geoderma, 72, 165-190.

Soil Survey Staff. 2014. Kunci Taksonomi Tanah. Edisi ketiga, 2015. Balai Besar Penelitian dan Pengembangan Sumberdaya Lahan Pertanian, Badan Penelitian dan Pengembangan Pertanian.

Sonneveld, M.P.W., Hack-ten Broeke, M.J.D., Diepen, C.A., \& Boogaard, H.L. 2010. Thirty 
Years of Systematic Land Evaluation in the Netherlands. Geoderma. 156, 84-92.

Sys, I.C., Van Ranst, B., \& Debaveye, J. 1991. Land evaluation. Part I. Principles in land evaluation and crop production calculations. International training center for post graduate soil scientists, University Ghent.

Utomo, M., Sudarsono, Rusman, B., Sabrina, T., Lumbanraja, J., \& Wawan. 2016. Ilmu Tanah
Dasar-dasar dan Pengelolaan. Prenadamedia Group. Jakarta

Wood, S.R., \& Dent, F.J. 1983. LECS. A Land Evaluation Computer System Methodology. Bogor: Ministry of Agriculture/PNUD/FAO, Centre for Soil Research, Indonesia

Zonneveld, I.S. 1989. The Land Unit - a Fundamental Concept in Landscape Ecology, and its Applications. Landscape Ecology. 3, 67-86. 